University of Michigan Law School

University of Michigan Law School Scholarship Repository

\title{
Preemption and Theories of Federalism
}

\author{
Robert R. M. Verchick \\ Loyola University New Orleans College of Law
}

\author{
Nina A. Mendelson \\ University of Michigan Law School, nmendel@umich.edu
}

Available at: https://repository.law.umich.edu/book_chapters/68

Follow this and additional works at: https://repository.law.umich.edu/book_chapters

Part of the Administrative Law Commons, and the State and Local Government Law Commons

\section{Publication Information \& Recommended Citation}

Verchick, Robert R.M. "Preemption and Theories of Federalism." Nina A. Mendelson, co-author. In Preemption Choice: The Theory, Law, and Reality of Federalism's Core Question, edited by W. Buzbee, 13-32. Cambridge: Cambridge University Press, 2009.

This Book Chapter is brought to you for free and open access by the Faculty Scholarship at University of Michigan Law School Scholarship Repository. It has been accepted for inclusion in Book Chapters by an authorized administrator of University of Michigan Law School Scholarship Repository. For more information, please contact mlaw.repository@umich.edu. 


\title{
1 Preemption and Theories of Federalism
}

\author{
Robert R.M. Verchick and Nina Mendelson
}

\section{INTRODUCTION}

American government is an experiment in redundancy, with powers and duties shared among federal, state, and local decision makers. The arrangement is designed to divide power, maximize self-rule, and foster innovation, but it also can breed confusion. In the areas of public safety and environmental protection, state and federal leaders (to name the two most active players in these disputes) are often seen jockeying for the inside track, hoping to secure the resources or authority needed to promote their views of the public good or gain politically. To outside observers, the best outcomes are not obvious. For example, should the federal government be the exclusive regulator of automobile pollution, as it is of automotive fuel efficiency, or should (as U.S. Senators from California successfully argued in 1967) California also be allowed to set its own unique, more stringent standards? Should New Jersey be able to issue regulations requiring chemical plant managers to consider safer technology to reduce the risks of terrorism incidents, or should those requirements be imposed only if the U.S. Department of Homeland

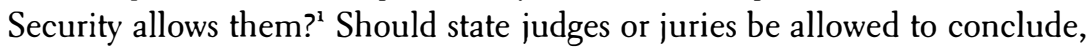
applying state tort law, that a pharmaceutical company has negligently failed to warn patients of drug side effects if the U.S. Food and Drug Administration has already approved the drug label? Deciding when federal law trumps state law can be a complicated process, involving the legislature, the judiciary, and even executive agencies. The guiding principles always include federalism.

Federalism is concerned with the distribution of power between the federal government and state governments. Most significantly, the Constitution gives

As this book was going to press, Congress expressly resolved this question by adopting a savings clause for state law on chemical plant security. Consolidated Appropriations Act, 2008, Pub. L. No. 110-161, $\int_{534}, 121$ Stat. 1844, 2075 (2007) (to be codified at 6 U.S.C. $\int 121$ note). 
Congress the power to make laws in areas affecting interstate commerce, military defense, and civil rights. This delegation of powers contemplates some impingements on state autonomy. Meanwhile the Tenth.Amendment reserves powers to the states. With a federal government of limited powers, and states wielding plenary powers, realms of separate sovereignty and political accountability might seem to be the norm. Yet the modern understanding of the Constitution's provisions leaves generous room for state and federal overlap. Within these boundaries, however, Congress can use its lawmaking powers either to leave space for state authority or else to eclipse, or preempt, state power. The Constitution's Supremacy Clause makes clear that state law must yield to federal law as supreme. Preempting state law is not unfair, according to federalism theory, because political safeguards built within the legislative process (such as the fact that Senators are elected state by state) deter federal lawmakers from routinely bulldozing over the states' interests. This chapter focuses on Congress's preemption power and examines the most common legal and theoretical issues surrounding its use.

The two most important questions about preemption are related. The first is for the lawmaker: when, or in what way, should Congress act to preempt state laws in favor of federal ones? The second is for the judge: how do you know that state law has been preempted? In answering the first question, policy makers must consider the relative strengths of federal and state regulation. A more centralized federal approach promises uniformity, and with it fewer transaction costs associated with compliance, the containment of transboundary "spillover" effects, and economies of scale. A more decentralized, state-based approach is associated with greater government responsiveness and citizen participation, allowances for regional variability, and helpful experimentation among states.

As for the second question, sometimes Congress's intent to preempt state law is clear and plainly stated in a statute. But sometimes there is doubt. A statute may not declare preemption outright but may conflict with state law; or it may be so broad as to "occupy the field" of targeted regulation, leaving states with no power in the area. The courts have articulated a presumption, discussed in greater detail in the sections that follow, against reading a statute to preempt state law where Congress's intent is not clear. That somewhat inconsistently applied presumption is informed, in part, by concerns about not trenching on state authority or eclipsing state sovereignty "accidentally" without full consideration by a federal deliberative legislature. Besides examining the issues related to congressional decisions to preempt state law, this chapter will also examine the theoretical assumptions underlying judicial reluctance to read a statute as preempting state law. 


\section{PREEMPTION AND THE CONGRESS}

Reading the Constitution, one might think it utterly clear, as some have argued, ${ }^{2}$ that the federal government can freely preempt state governments from regulating the environment, pharmaceutical safety, employment relationships, or nearly any other subject that is within Congress's legislative authority. After all, the Constitution's Supremacy Clause states, "This Constitution, and the Laws of the United States which shall be made in Pursuance thereof . . . shall be the supreme Law of the Land; and the Judges in every State shall be bound thereby, any Thing in the Constitution or Laws of any State to the Contrary notwithstanding" (art. VI, cl. 2). Moreover, courts have long read the Commerce Clause, which authorizes Congress to regulate "Commerce ... among the several States" (art. II, Sec. 8, cl. 3), as an independent prohibition of state laws that discriminate against or unduly burden interstate commerce.

In short, Congress could make policy for the nation, and its choices would be supreme notwithstanding contrary state government views. Assuming Congress is properly using its constitutional powers (such as the power to regulate commerce), the only constitutional obstacle might be the Tenth Amendment, which suggests that some powers "not delegated to the United States . . . are reserved to the States respectively, or to the people." But that amendment has been interpreted by the courts to restrain Congress from preempting state authority only narrowly - by, for example, "commandeering" state employees or resources to enact or administer a federal regulatory program." 3 As we see it, the Tenth Amendment todaypresents no other obstacle to federal preemption even in traditionally "local" fields such as the protection of health and safety.

Despite Congress's broad preemptive power, many, if not most, areas of law are governed concurrently by federal and state governments. Lively debate continues in many settings about whether state regulatory authority should be forced to yield to federal power or whether Congress has actually acted to preempt state law and to what extent. The "presumption against preemption" applied by courts tends to moderate the extent to which states will be barred from regulating. Congress regularly legislates to share power or to preserve state authority.

Given an effective federal government with far-reaching power to regulate, why preserve state authority to regulate? Debates on whether to preempt state

2 See Caleb Nelson, "Preemption," Virginia Law Review 66, no. 3 (2000): 225.

3 See Printz v. United States, 521 U.S. 898, 933 (1997) (quoting New York v. United States, 505 U.S. 144, 157 [1992]). 
law often draw on ideas of federalism - a general concern with the division of power between the federal and state governments and with maintaining core attributes of state sovereignty. A state's authority to devise its own laws is among these core aspects of state sovereignty. ${ }^{4}$ As developed in a recent series of cases, another core aspect is preserving a state's sovereign immunity from private lawsuits seeking money damages, a protection emphasized by a now expansively interpreted Eleventh Amendment. ${ }^{5}$

Federalism advocates identify several benefits of preserving a state's sovereignty and autonomy to regulate. First, some argue that strong state authority, of which authority to regulate is a part, is important to the scheme of separation of powers developed by the Framers of the Constitution. Like the division of powers among the judicial, executive, and legislative branches of the federal government, maintaining significant state government power can help avoid the undue concentration of power in the federal government and preserve essential individual liberties. ${ }^{6}$ Moreover, where a federal program depends on state and local implementation or cooperation, the involvement of states might prompt the federal government toward helpful moderation of its policies. For example, after Congress enacted the USA Patriot Act, many state and local governments objected, with some directing their officials not to participate in parts of the program. ${ }^{7}$

Second, if states possess robust authority to regulate, the policies chosen within a state will tend to be tailored to local concerns and to citizen preferences. For example, some western and southwestern states, where spicy Mexican candies are popular, monitor and regulate those candies for contamination with lead dust. ${ }^{8}$ Although lead dust in these candies presents a significant safety threat, especially to children, the federal

4 See Robert R. M. Verchick, "The Commerce Clause, Environmental Justice, and the Interstate Garbage Wars," Southern California Law Review 70, no. 5 (1997): 1239.

5 Alden v. Maine, 527 U.S. 706 (1999); Coll. Sav. Bank v. Fla. Prepaid Postsecondary Educ. Expense Bd., 527 U.S. 666 (1999); Fla. Prepaid Postsecondary Educ. Expense BD. v. Coll. Sav. Bank, 527 U.S. 627 (1999).

6 See, e.g., Atascadero State Hospital v. SCanlon, 473 U.S. 234, 242 (1985) (the "'constitutionally mandated balance of power' between the States and the Federal Government was adopted by the Framers to ensure the protection of "our fundamental liberties"').

7 See Susan Schmidt, "PATRIOT Act Misunderstood, Senators Say; Complaints About Civil Liberties Go Beyond Legislation`s Reach, Some Insist," WASh Ington Post, October 22, 2003, $\mathrm{A}_{4}$ (noting "nearly 200 cities and three states have passed resolutions contending that the PATRIOT Act . . . tramples on civil liberties"); Ann Althouse, "The Vigor of Anti-Commandeering Doctrine in Times of Terror," Brooklyn Law Review 69, no. 4 (2004): 1253.

8 E.g., Deborah Vanpelt, "State Fears Candies Pose Health Risk; Mexican suckers pulled from shelves," TAmpa Tribune, December 9, 1994, 1 (describing efforts of Florida, California, Texas, and Arizona with respect to Mexican candies). 
government failed for several years to give high priority to this regional issue. ${ }^{9}$

Third, preserving state regulatory authority may also benefit citizens by prompting greater engagement in government. Citizens are often presumed to be able to participate more directly in policy making at the state level. Greater state autonomy to regulate will mean more opportunities for citizens to participate in governance and seek responsive government. That may result in greater "civic virtue" in citizens by encouraging them to become better informed and more actively engaged in all levels of government. ${ }^{10}$ Although it has been a benefit claimed for federalism, the goal of stimulating greater citizen engagement may logically lead to calls for concentrating power in localities, such as cities, rather than states. ${ }^{11}$

Fourth, preserving state authority to regulate can mean, in the words of Justice Louis Brandeis, that the states are able to function as "laborator[ies]" that can try "novel social and economic experiments" to solve society's problems. Other states and the federal government may learn from or adopt one state's innovative approach, ultimately benefiting the entire country. ${ }^{12}$ To take this a step further, some scholars now argue that such regulatory innovation sets up a "competitive interaction" between the federal government and the states and among the states. ${ }^{13}$ Professor Robert Schapiro develops this claim further in Chapter 2. Because citizens can compare the different responses of the federal and state governments to a particular problem, they may be better able to understand the range of options and hold government officials accountable for an inadequate response. That may in turn prompt regulators to be more thorough and more responsive to citizen preferences. For example, recent state and municipal efforts to reduce greenhouse gases

9 In October 2006, the FDA finally issued guidance to industry indicating that if lead levels in candy likely to be eaten by small children exceeded the recommended level of 0.1 parts per million, the candy manufacturer could face enforcement action. See U.S. Food and Drug Administration, "Guidance for Industry: Lead in Candy Likely to be Consumed Frequently by Small Children," (October 2006) (available at http://www.fda.gov/OHRMS/DOCKETS/g8fr/ 05d-0481-gdlooo2.pdf).

10 See, e.g., Gregory v. Ashcroft, 501 U.S. 452, 458 (1991).

"See Frank Cross, "The Folly of Federalism," Cardozo Law Review 24, no. 1 (2002): 1.

12 See New State Ice Co. v. Liebmann, 285 U.S. 262, 311 (1932) (Brandeis, J., dissenting) (describing states as "laborator[ies]").

13 Kirsten Engel, "Harnessing the Benefits of Dynamic Federalism in Environmental Law," Emory Law Journal 59, no. 1 (2006): 159; Roderick Hills, "Against Preemption; How Federalism Can Improve the National Legislative Process," New York University Law Review 82, no. 1 (2007): 1; Robert Schapiro, Polyphonic Federalism: How a Federal. System Protects Fundamental Rights (Chicago: University of Chicago Press, forthcoming); William W. Buzbee, "Asymmetrical Regulation: Risk, Preemption, and the Floor/Ceiling Distinction," New York University Law Review 82, no. 6 (2007): 1547. 
and address climate change have prompted a national dialogue questioning the extent of federal action on climate change. And federal action can also sidestep the pervasive risk of state failure to address a risk due to "free rider" temptations that could lead all states to delay in the hope that others will act.

Notwithstanding the federalism-related benefits of preserving state authority to regulate, there still may be reason to limit state control over a particular regulatory issue or to supplement it with federal regulation. A federal, rather than a state-focused, approach is more likely to effectively address problems that cross state lines. Consider a factory that dumps pollution in a rural Illinois river, making the river downstream, next to a populous Missouri town, unswimmable and undrinkable. The upstream state government may not have a strong incentive to take into account the harm to downstream, outof-state residents - a "negative externality" from an in-state activity that may generate jobs and tax revenue. The federal government accordingly may select more appropriate water pollution standards. In addition, a uniform federal approach will minimize the risk that states will "race to the bottom," competing with each other to loosen their environmental or other standards so as to attract new business. ${ }^{14}$ Recent scholarship by Dean Richard Revesz argues that state regulators likely will select environmental standards that maximize citizen welfare overall rather than "racing to the bottom."15 Other scholars, including Professor Kirsten Engel, disagree, persuasively arguing that politicians may have a strong incentive to be perceived as doing "everything possible" to attract a new business to the state, including relaxing environmental standards below an optimal level. ${ }^{16}$ At a minimum, this scholarship raises important questions about whether state regulation may sometimes be affected by pathologies causing state regulators to choose less-than-optimal levels of environmental protection.

Finally, a national standard can give each citizen an assurance - even something of an entitlement - to a minimum level of safety, health, or environmental protection, no matter where he or she resides. A single federal approach, without separate state standard-setting, also has advantages for regulated entities. Those who must comply with regulation can face a

${ }^{14}$ Scott R. Saleska and Kirsten H. Engel, “Facts Are Stubborn Things': An Empirical Reality Check in the Theoretical Debate over the Race-to-the-Bottom in State Environmental Standard-Setting," Cornell Journal of Law and Public Policy 8, no. 1 (1998): 55-62 (describing "race to the bottom" in environmental context, whereby relaxation of local standards leads to decline in locality's social welfare).

15 E.g., Richard L. Revesz, "The Race to the Bottom and Federal Environmental Regulation: A Response to Critics," Minnesota Law Review 82, no. 2 (1997): 535.

16 See Saleska and Engel, "Facts Are Stubborn Things," SuPRA n. 14, at 74-84. 
regulatory regime that is more certain and uniform and thereby avoid multiple layers of regulation, which not only may be costly to comply with but also may be costly to figure out. This is one reason why regulated entities have frequently sought preemption. Pro-preemption arguments can have particular force when the regulatory requirement consists of a design requirement, such as specifying air-bag requirements for cars. Multiple design requirements could result in very high costs of compliance as manufacturers retool their assembly lines for different state requirements.

A unitary federal approach might also save resources, as only one government, the federal government, would invest its resources in developing regulatory standards. A fully encompassing federal regulation thus might benefit from economies of scale. Congress has sometimes completely preempted state regulatory requirements, as with the federal motor vehicle safety standards.

A very appealing approach is to capture benefits on both sides by creating a hybrid, power-sharing arrangement between the federal government and the states. For example, as in many environmental laws, Congress may specify that federal law serve as a "floor" of minimum protection but that states remain free to adopt standards that are more protective of health or the environment. That gives citizens a minimum level of protection but leaves states free to experiment or satisfy local calls for stricter protection. Even with federal environmental standards in place, some citizens may still face acute localized risks, called "hot spots" by environmentalists; preserving state authority to go beyond federal standards can allow an effective response to these local problems. ${ }^{17}$ Alternatively, even if a particular consumer product does not violate federal standards, individuals injured by the product may still be free to go to state court and argue that under state tort law requiring, say, reasonable care, the manufacturer should be liable for product defects or failure to warn consumers. The continuing availability of tort claims is likely to prompt the manufacturer to address safety concerns that regulators have not yet anticipated.

In addition, as some have argued in the environmental setting, concurrent state and federal authority furthers the goal of precaution, by ensuring that the more stringent standards, whether national or local, take precedence. States

${ }^{17}$ See Zygmunt J. B. Plater et al., Environmental Law and Policy: Nature, Law, and Society (New York: Aspen Publishers, 2004), 335 (discussing benefits of "savings" clauses in federal legislation); Robert R. M. Verchick, "Fair Distribution of Environmental Harms and Benefits," in A New Progressive Agenda for Public Health and the EnvironMENT, ed. Christopher Schroeder and Rena Steinzor (Durham, NC: Carolina Press, 2004) (discussing distributional harms in environmental policy). 
are generally barred from adopting environmental standards that are less protective than federal ones.

Finally, states implementing federal law under "delegated program" structures typically undertake significant responsibility to implement a federal program by, for example, developing their own individual requirements that will meet a federal program's goal or by issuing permits to individual companies or other entities that must comply with federal law. States thereby may retain greater flexibility to respond to local concerns - and to counterbalance federal authority - but within the framework of a federal program that seeks to address a particular issue at a national level.

Assuming that the states and the federal government do not require, say, disparate design standards, these sorts of power-sharing approaches can be advantageous and workable. They can help prevent "races to the bottom" and protect against federal inaction or other regulatory pathologies at both levels of government. However, they still may impose the burden on a particular company or entity of having to comply with more than one regulatory standard in a particular location.

Assuming the importance of federalism interests and a state's autonomy to regulate, how might those interests best be protected in a federal regime? One position is that the federal legislative process can adequately protect state autonomy. The Supreme Court has cited this "political safeguards" approach, for example, in declining to judicially enforce the Tenth Amendment, with the exception of the anti-commandeering requirement, as a constraint on federal power over state governments.

According to the "political safeguards" approach, Congress will select the appropriate balance between federal and state authority and will credit the need for state authority and autonomy. ${ }^{18}$ First, state officials and organizations (such as associations of governors and attorneys general) frequently present their views through testimony to Congress or through informal means. Further, members of Congress are elected by district or by state, and so have an incentive to take state interests into account in considering legislative proposals. Moreover, Congress generally wants the cooperation and support of state governments in its programs and so will consistently consider state interests. Finally, because voters generally favor federalism values, members of Congress, responsive to electoral views, will also support state interests. 
But not everyone accepts the "political safeguards" view. Some experts contend that because there is no guarantee that Congress will protect state interests, courts should help preserve state autonomy and authority by independently enforcing states' rights. ${ }^{19}$ For example, as discussed earlier, judges have been willing to strike down federal statutes as violating the Tenth Amendment because they "commandeer" state resources for use in federal programs. Some also might characterize the judicial presumption against preemption, discussed in the next section, as a lesser form of independent judicial protection of state authority and autonomy.

\section{PREEMPTION AND THE COURTS}

Even once Congress has enacted a federal statute, with a full opportunity for states and state organizations to have their views heard, whether the statute preempts state law and to what extent may not be altogether clear. Congress may not foresee a relevant change, such as a change in technology or in state regulatory practice. For example, some have criticized the preemption language in the Employment Retirement Income Security Act (ERISA), which covers employee benefit plans; despite dramatic changes in the health care system - including an explosion of managed health care plans - the act has yet to be seriously updated. ${ }^{20}$ Sometimes Congress will deliberately not answer a preemption question because its members cannot reach agreement. For example, in the fall of 2006, Congress debated whether states should be preempted from requiring any further federal chemical plant security measures beyond those required under federal law. Congress could not reach agreement at the time, and 2006 legislation requiring the setting of federal chemical plant requirements included no language either preempting state law or "saving" state law. And of course, sometimes statutory language is written in a way that is unintentionally vague or incomplete.

When faced with such a statute in the context of a dispute over whether state law is preempted, courts must interpret the statute to decide whether it preempts the state from regulating. As discussed in greater detail by Professor Schroeder in Chapter 6, a court may conclude that Congress has "expressly preempted" state law, usually through statutory language that specifies which laws are preempted. Courts also may infer (through "implied preemption"

19 E.g., Frank B. Cross, “The Folly of Federalism," Cardozo Law Review 24, no. 1 (2002): 1, 8-12; Marci A. Hamilton, "The Elusive Safeguards of Federalism," Annals of AmErican ACADemy of Political and Social Science 574 (March 2001): 94.

20 E.g., Donald Bogan, "Protecting Patients' Rights Despite ERISA," Tulane Law Review 74, no. 3 (2000): 951 . 
analysis) preemptive intent when state law "conflicts" with the federal law. Sometimes conflict arises when compliance with both state and federal law is physically impossible. Other times a court will find conflict when a state law poses an obstacle to the full accomplishment of a federal goal ("obstacle preemption"). Finally, a court might conclude, as the Supreme Court has with immigration law, that Congress has "occupied the field" of a particular regulatory area. This form of preemption, called "field preemption," is based both on congressional intent and on whether the federal government has traditionally controlled regulation in the area. ${ }^{21}$

In determining whether Congress has preempted state law, modern courts have generally applied a presumption against preemption, especially in regulatory areas commonly left to the states. Courts have refused to find state law preempted unless a federal statute provides a "clear statement" that state law is to be preempted or other strong evidence that preemption is the "clear and manifest purpose" of Congress. ${ }^{22}$

How might the presumption be justified? A plausible response is that it is not justified at all, because Congress possesses the largely unfettered power to preempt state law freely. The correct judicial response to a statute that might preempt state law accordingly might be to apply no presumption. But sometimes courts need a "tiebreaker" to resolve whether an ambiguously worded statute actually does preempt state law. As a clear "default" rule used to break such ties, the presumption against preemption also provides Congress with greater certainty about how courts will interpret statutory language that does not clearly address preemption. ${ }^{23}$

Even though the use of some clearly stated tiebreaker by judges is useful, the question remains whether the judicial choice of the particular default ruleagainst preemption - is the right choice or an inappropriate "thumb on the scale." Congress frequently guards state interests. Perhaps, then, the presumption against preemption follows a reasonable assumption that unless Congress says otherwise, it does not intend to limit state regulation. However, congressional intent with respect to state law is not always clear. In the absence of legislative language that "saves" state law, perhaps courts should assume that Congress's main concern is the effectiveness of federal law, a priority that overrides state law with conflicting rules or values.

21 See, e.g., Hines v. Davidowitz, 312 U.S. 52, 74 (1941) (finding Pennsylvania alien registration law preempted).

22 See, e.g., Rice v. Santa Fe Elevator Corp., 331 U.S. 218, 230 (1947), quoted in MedTRONIC, INC. v. LOHR, 518 U.S. 470, 485 (1996).

23 See Nina Mendelson, "Chevron and Preemption," Michigan Law Review 102, no. 3 (2004): $737,745-46$. 
If the presumption against preemption does not represent a judge's best guess at Congress's actual intent, how else might it be understood? By requiring a clear statement or some other strong evidence from Congress that it intends preemption, judges can reduce the chance of Congress thoughtlessly eclipsing state sovereignty. For example, if the statute specifically mentions state law preemption, it increases the chances that state law preemption will have received actual discussion in Congress. Thus, absent a clear statement or strong evidence, a presumption against preemption promotes legislative deliberation. Professor Bradford Clark, in Chapter 9, embraces this presumption, rooting his argument in the Constitution's language and structure.

In addition to a procedural bias in favor of more deliberation, a clear statement rule also imposes a substantive bias in favor of state autonomy. By raising the bar to establish preemption, the rule effectively protects a larger field of state authority. That may serve a judicial desire to minimize congressional tampering with the federal-state framework and, in the words of the Supreme Court, to avoid "serious intrusion into state sovereignty." 24 The effect is to give state autonomy and authority some additional protection in court beyond what states have been able to obtain in the political process. Although such an approach seems inconsistent with the "political safeguards" approach embraced by the Supreme Court in other settings, advocates of this approach stress the constitutional importance of the federal-state balance and argue that relaxing judicial constraints might put the federal fox in charge of the states' chicken coop. They argue that courts should more actively patrol the line between states and the federal government as part of reinforcing the constitutional structure and supporting the "tradition" of federalism. ${ }^{25}$

But applying a presumption against preemption also has significant downsides. For instance, insisting that courts always attempt to read statutes without clear preemptive language in the states' favor can force courts to adopt a more "federalist" interpretation of a statute even when that interpretation is not the best reading of the statute's language. Ours is a country of "laws, not men." ${ }^{26}$ Too many deviations from statutory language by judges can undermine the integrity of the law. At its worst, the presumption against preemption could become a cloak for illegitimate judicial policy choices - enabling what Professors William Eskridge and Philip Frickey call "under-the-table constitutional lawmaking." 7

24 See Medtronic, Inc., v. Lohr, 518 U.S. 470, 488 (1996).

25 See sources cited SUPRA n. 19.

26 The phrase has been attributed to Livy. See Harold Bruff, "The Incompatibility Principle," Administrative Law Review 59, no. 2 (2007): 225.

27 William N. Eskridge and Philip P. Frickey, "Quasi-Constitutional Law: Clear Statement Rules as Constitutional Lawmaking," Vanderbilt Law Review 45, no. 3 (1992): 593, 635 (discussing clear statement rules). 
Judges might simply be sneaking policy through the "back door," using the presumption against preemption to impose their own views of the correct balance of state and federal power. States can adequately protect the prerogative to regulate through their influence in Congress, and judges should be discouraged from displacing Congress by trying to minimize federal preemption of state law. ${ }^{28}$

On this view, the judiciary might leave the question of state law preemption wholly to the political process, applying no presumption at all. Some argue that the policy choices involved in preserving or preempting state authority to regulate are more appropriately made on a case-by-case basis by Congress, our most democratic institution and the one most accountable to voters. The argument is even stronger, given Congress's clear power under the Constitution's Supremacy Clause to preempt state law as part of exercising its other constitutional authorities.

In our view, preemption advocates make a persuasive claim - up to a point. Congress clearly has the prerogative to preempt state law and should not be forced to express that desire in any unusually specific or clear way as long as the ultimate meaning can be discerned. But where there is significant ambiguity, a rule favoring state authority is, it seems to us, appropriate. Such a clear intent rule would foster uniformity among courts and acknowledge the traditional interests in local control, while at the same time preserving for the Congress maximum latitude in expressing its desires. Professor Clark examines compromise positions like this more completely in Chapter 9 .

\section{SPECIAL CASES}

Disagreements about preemption, in the courtroom and in the academy, tend to revolve around certain kinds of cases in which the merits of federal or state interests seem particularly strong. Such "special cases" often involve questions about which branch is asserting preemption, the nature of the laws being preempted, or both. Another notable case involves federal provisions designed to "save" a role for state decision making. We emphasize the special cases for three reasons. First, they test the endurance of preemption advocates and skeptics by asking just how far each will go in defending a theoretical position. Second, special cases sometimes point to weaknesses in a background rule, suggesting the need for fine-tuning or even exceptions. Finally, because these cases are drawn from current controversies in law and politics, they acquaint 
readers with the new frontiers of preemption analysis. Here is where the rubber meets the road.

\section{Who Is Preempting?}

Should preemption analysis change according to who is asserting preemption? Our analysis so far has assumed that Congress, explicitly or implicitly, commands the preemption. But as discussed in greater depth in Professor William Funk's accompanying Chapter 10, recently we have seen a trend in which state preemption is imposed not by Congress, but by executive agencies. In 2005, for instance, the Food and Drug Administration took the position that its labeling requirements for tuna preempted California's efforts to add any additional warnings on the product. ${ }^{29}$ The California label would have warned consumers about the threat of mercury contamination; the FDA would have required no warning label. That same year, the U.S. Department of Transportation issued a proposed rule finding that its new "roof crush" standards for automobiles would preempt any additional requirements at the state level including findings of liability under state tort law. ${ }^{30}$ Sometimes, preemption is specifically authorized by Congress in the formative statute. Sometimes, as in the preceding examples, it is not. Agency-made regulation, if the agency is properly exercising the authority it received from Congress, can have the same preemptive effect as a federal statute. ${ }^{31}$ And if compliance with both an agency regulation and state law is physically impossible, the agency regulation clearly prevails over the state law. Beyond this, courts and scholars disagree about how to interpret the bounds of underlying congressional authority. Must Congress expressly delegate to an agency the right to upend state law through regulatory act? Or may an agency infer such authority from less explicit or even ambiguous statutory language? If the latter, may agencies infer preemptive powers whenever convenient, or only as a "last resort" to accomplish federal goals?

29 See U.S. Food and Drug Administration, "Letter to Bill Lockyer re a Suit Filed on June 21, 2004, People of the State of California v. Tri-Union Seafoods" (August 12, 2005) (available at www.cfsan.fda.gov/ dms/f-ltr65.html).

30 See National Highway Traffic and Safety Administration, Department of Transportation, "Proposed Rule: Federal Motor Vehicle Safety Standards; Roof Crush Resistance," FederaL Register 70 (August 23, 2005): 49,223.

31 See, e.g., Louisiana Pub. Serv. Comm'n v. FCC, 476 U.S. 355, 369 (1986). ("Pre-emption may result not only from action taken by Congress itself; a federal agency acting within the scope of its congressionally delegated authority may pre-empt state regulation."); FIDELITY Federal Savings and Loan Assn. v. De la Cuesta, 458 U.S. 141, 153 (1982). ("Federal regulations have no less pre-emptive effect than federal statutes.") 
A pro-preemption argument would assert that despite the agency twist, the federal actors should remain supreme. Federal agencies are enforcers of legislative command, and courts should interfere as little as possible with the federal enforcement of federal law. Moreover, as enforcers and implementers of federal statutes, agency officials have the closest understanding of how to achieve federal goals. ${ }^{32}$ Agency officials are the first to know if the accomplishment of their delegated mission has been jammed by state "obstacles" or transformed into a functional "impossibility." In addition, although agencies are naturally focused on federal goals, they have incentives to consider state interests and federalism values. Top executive agency officials are appointed by and report to the President, and, even in relatively liberal administrations, the White House has guarded traditions of federalism. For instance, President Clinton's Executive Order 13,132 ${ }^{33}$ directs all federal agencies to be mindful of state powers when implementing federal law and specifically directs agencies (when possible) to favor interpretations that do not preempt state laws. ${ }^{34}$ Should these safeguards fail, Congress always retains the power to correct agency overreaching by amending the authorizing statute. For example, in response to attempts by the Department of Homeland Security to preempt state security laws governing chemical facilities, Congress recently enacted a savings clause that preserves state law unless it actually conflicts with federal law. ${ }^{35}$

Preemption skeptics argue that regulatory preemption must be carefully contained. Agency officials are not directly accountable to voters, they warn, and agencies lack consistent White House supervision, whatever the executive orders say. Federal agencies are, by design, focused on federal needs and powers rather than state interests. As a practical matter, federal agencies are not set up to evaluate and protect state regulatory powers - and they rarely do. ${ }^{36}$ By invoking obstacle preemption, a creative agency could preempt nearly any sort of state regulation simply by referencing a subordinate federal purpose that is somehow impeded by the state law. ${ }^{37}$ Federal agencies are also sometimes subject to "capture" by big business and other powerful lobbies.

32 Robert R. M. Verchick, “Toward Normative Rules for Agency Interpretation: Defining Jurisdiction under the Clean Water Act," Alabama Law Review 55, no. 3 (2004): 845.

33 Federal Register 64 (1999): 43,255.

34 But research suggests the directive is seldom followed. See Mendelson, SUPRA n. 23, at 783-4 (documenting remarkably low compliance by agencies with Executive Order 13,132).

35 See Supra n. 1.

${ }^{6}$ See Supra. n. 34.

37 See Nina Mendelson, "A Presumption against Agency Preemption," Northwestern UniVERSITY LAW REVIEW 102, no. 2 (2008): 695. 
All this makes an agency particularly ill-suited to weigh the interests of state and local interests in the course of accomplishing federal goals.

On this issue, we side with preemption skeptics. Agencies lack the expertise to evaluate the federal-state balance, and it is unclear how serious an incentive they face to fully consider state interests. Accordingly, absent clear evidence that Congress intended to grant such authority to agencies, general rulemaking delegation language should not be read to include the authority to preempt state law.

In 2007, the Supreme Court almost tested this argument in Watters v. Wachovia Bank. ${ }^{8}$ In a 5-3 decision (Justice Thomas did not participate), the Court upheld a policy of the U.S. Comptroller of the Currency that shielded real estate lending by national banks from state consumer protection laws. The Comptroller's office had based its policy on the National Bank Act's general grant of authority to prescribe "restrictions and requirements" for real estate lenders. ${ }^{39}$ The four appellate circuits examining the policy had found that although the statute did not preempt state consumer protection laws, the Comptroller's policy had; and because the statute granted the Comptroller broad powers, that agency-made preemption was just as valid as if it had been penned by Congress. ${ }^{40}$ But in upholding the Comptroller's policy, the Supreme Court refused that gambit. Instead it found, perhaps implausibly, that the banking statute had preempted state consumer protection laws all along. ${ }^{41}$ As a result, there was no need to decide whether a federal agency, on these or any other facts, has the independent power to preempt state law when Congress is mute.

Still, the case is instructive. For one thing, it shows the murky progression from legislative to agency-based preemption: it is not always easy to tell where one ends and the other begins. For another, Wachovia Bank reminds us that courts can interpret a set of facts in surprisingly different ways, bypassing (or, some might say, deliberately avoiding) questions or doctrines that at first seem relevant. Finally, Wachovia Bank teaches us to pay attention to the national or local features of the subject matter involved. In reaching its conclusion, the Court repeatedly emphasized the national significance of the interstate banking system, a network now more than one hundred years old and deeply embedded in the federal-state structure. Perhaps a different case, involving a less traditional federal role or a less pervasive statutory system, would come

$3^{8} \quad 127$ S.Ct. 1559 (2007).

39 Office of Comptroller of the Currency, "Notice: Preemption Determination and Order," Federal Register 68 (2003): 46,264.

40 See Wachovia Bank, 127 S.Ct. at 1579 n. 16 (Stevens, J., dissenting) (citing cases).

${ }^{41}$ See id. at 1569 . 
out differently. We examine the importance of regulatory subject matter in the next subsection.

\section{What Is Being Preempted?}

Perhaps courts should adjust their standards for preemption according to what sort of state or federal regulation is at stake. Judges already do this in some ways, although not always clearly or consistently. As generally understood, the presumption against preemption requires courts to "start with the assumption that the historic police powers of the States were not to be superseded ... unless that was the clear and manifest purpose of Congress." 42 The implication is that the presumption is most powerful where "the State's historic police powers" have been threatened. ${ }^{43}$ In contrast, the presumption may have less force "when the State regulates in an area where there has been a history of significant federal presence." 44

Where federal lawmakers cut too close to the bone, the Supreme Court has occasionally gone further, requiring not just clear evidence of preemptive intent (an approach we favor), but a clear statement of intent within the statute. Thus, in Gregory v. Ashcrof ${ }^{45}$ the Supreme Court read a broad federal statute prohibiting age discrimination in employment not to cover state judges, leaving in place the state's constitutional requirement that state judges retire by age seventy. Writing for the majority, Justice Sandra Day O'Connor warned that the Court should not "upset the usual constitutional balance of federal and state powers" unless Congress made "its intention to do so unmistakably clear in the language of the statute." 46 Finding no clear statutory language intended to displace core state functions, the majority held that the age discrimination statute did not apply to state judges. In the environmental area, courts have rejected agency statutory interpretations that might "encroach upon a traditional state power." 4

42 Rice v. Santa Fe Elevator Corp., 331 U.S. 218, 230 (1947).

43 Geier v. Am. Honda Motor Corp., 529 U.S. 861, 894 (2000) (Stevens, J., dissenting).

44 United States v. Locke, 529 U.S. 89, 108 (2000). In addition, there is no presumption against preemption when a state intrudes on the sovereign prerogatives of the federal government by directly regulating the federal government or its agents. See generally Seth P. Waxman and Trevor W. Morrison, "What Kind of Immunity? Federal Officers, State Criminal Law, and the Supremacy Clause," Yale Law Journal 112, no. 8 (2003): 2195.

45501 U.S. 452 (1991).

$4^{6}$ Id. at 460-1 (quoting Atascadero State Hospital v. Scanion, 473 U.S. 234, 242 [1985]) (internal quotation marks omitted).

47 See Solid Waste Agency of Northern Cook County v. U.S. Army Corps of EngiNEERS, 531 U.S. 159, 172-3 (2001) (invalidating agency rule that asserted federal jurisdiction over certain intrastate waters under the federal Clean Water Act). 
These practices have created a kind of "special case" analysis in which judges are reluctant to read federal laws to upset "historic" powers, "core" authority, or "traditional" balance. The rationale goes back to the debate about the Tenth Amendment and "political safeguards." Recall that, under today's understanding of the Constitution, the Tenth Amendment has been interpreted to protect state sovereignty in court in only limited ways, when federal law threatens to outright "commandeer" local executive or legislative resources. This understanding supplanted an earlier view, held a quarter century ago, that exclusively reserved to the states certain core powers, such as the authority to set labor standards for state employees. ${ }^{8}$ That view was abandoned in the 1985 case Garcia v. San Antonio Metropolitan Transit Authority. ${ }^{49}$ The effect was that state powers would now, for the most part, be protected by Congress through the political process, rather than through categorical judicial standards. However, the Gregory case adds a gloss to this rule by imposing a high burden to show congressional intent to interfere with core state functions before a court will read a federal statute to regulate those functions. As the Court in that case put it: "[I]nasmuch as this Court in Garcia has left primarily to the political process the protection of the States against intrusive exercises of Congress' Commerce Clause powers, we must be absolutely certain that Congress intended such an exercise."

Suggesting that a state law most deserves protection from preemption when it implicates a "core power" is not without difficulties. For one, it is sometimes hard to determine when a core power is at stake and when it is not. Is a federal law banning guns near schools a law about crime or about the local educational environment? Are federal restrictions on wetlands development more properly seen as national environmental protections or intrusions on the local core power of land-use planning? In addition, what should one do when a core state power confronts a core federal power? Wachovia Bank, for instance, pitted Michigan's traditionally local interest in consumer protection against the federal government's traditionally national interest in banking. Was the Court correct in refusing to apply a presumption against preemption in this special case? New Jersey's effort to impose additional safety requirements on local chemical plants suggests a similar situation. There the state's traditionally local interest in public safety overlapped with the federal government's national interest in homeland security. For our part, we find arguments based on endemic powers very problematic. Sorting governmental interests is not like sorting checkers. Often particular regulatory interests cannot be assigned

$4^{8}$ See National League of Cities v. Usery, 426 U.S. 833 (1976).

49469 U.S. 528 (1985).

50 Gregory, 501 U.S. at 464 . 
to one side or the other; instead they are negotiated and shared. Modern theories of cooperative federalism and instrument choice emphasize this point. In addition, the categories used to define government objectives, like public safety or homeland security, are too easily manipulated by those aiming for a specific result.

Still, it is possible to imagine other special cases where the state powers subject to preemption seem unusually important or deserving of protection. In Chapter 4, for example, Professor Morrison would require a clear statement of intent before a federal law can be invoked to preempt "the core enforcement activities of an elected state attorney general." 51 This rule, in his view, would promote local self-governance, by deferring to local law-enforcement interests pursued by a popularly elected state law-enforcement official. It would promote national democratic accountability by forcing Congress to specifically consider and issue a statement about preemption in this area before its laws could be used to undermine such local law-enforcement efforts.

\section{What Do "Savings Clauses" Save?}

As we mentioned earlier, federal statutes concerned with public health or the environment often include a provision that preserves a state's right to regulate in an even more protective way. In the last decade, such provisions, called "savings clauses," have stirred controversy in the federal courts. As Professor Sandi Zellmer shows in Chapter 7, these clauses have received erratic treatment in the courts. Should savings clauses be interpreted broadly, as preemption skeptics argue? Or should they be read narrowly, as urged by advocates of national uniformity? The issue is ostensibly one of statutory interpretation. But because Congress can usually share or hoard its power as it sees fit, one's assessment often appears linked to views about federalism.

In United States v. Locke, ${ }^{52}$ the Supreme Court unanimously held that the federal Oil Pollution Act of 1990, despite the existence of several savings clauses, preempted Washington State's ability to regulate oil tankers operating in state waters. The Court reasoned that because the savings clauses appeared in a section of the statute titled, "Oil Pollution Liability and Compensation," their otherwise broad language must be restricted to liability rules and could not be read to permit "substantive regulation of a vessel's primary conduct." 53

51 See Trevor W. Morrison, ch. 4, "The State Attorney General and Preemption." Morrison would include an exception for cases in which compliance with both the state and federal laws was physically impossible.

52529 U.S. 89 (2000).

53 Id. at 105. 
As in the federal banking cases, the Court also emphasized the "federal" nature of the subject matter - in this case the "at-sea conduct of vessels" declining to "give broad effect to savings clauses where doing so would upset the careful regulatory scheme established by federal law." 54

Later in the same term, the Supreme Court narrowly construed another savings clause on a slightly different theory. In Geierv. American Honda Motor Co. ${ }^{55}$ the Court ruled 5-4 that a federal motor safety law preempted a state tort action alleging design defect for failure to include an air bag. Although the act expressly preempted "any safety standard" different from the federal standard, it included a savings clause stating that compliance with a federal standard "does not exempt any person from any liability under common law." ${ }^{56}$ Nevertheless, the savings clause was insufficient to rescue the "no air bags" tort claim. The Court reasoned that the tort suit presented an obstacle that "conflicts" with the federal goal of preserving manufacturer flexibility to phase in air bags, thus creating a case for implied preemption. ${ }^{57}$ The savings clause, the Court found, was not worded in a way to save state laws from implied preemption. Rather, the clause seemed targeted only at the express preemption contained in the "any safety standard" language.

The Geier opinion left many lawyers wondering what a savings clause is now able to save. The majority insisted that it had not changed any background preemption rules and suggested that savings clauses could negate obstacle preemption if properly worded, although it did not say how. ${ }^{58}$ Justice Stevens, in dissent, accused the majority of unfurling a blanket rule that would always protect obstacle preemption from savings clauses. ${ }^{59} \mathrm{He}$ suggested the majority had dumped the traditional presumption against preemption in favor of the more immediate needs of the Department of Transportation. ${ }^{60}$

Can Congress, through a savings clause, deactivate implied preemption when state law poses obstacles to federal goals? Does such a functional barrier now conjure (as Justice Stevens decries) a sort of presumption against the presumption against preemption? The answer to the first question is presumably yes, because Congress in theory is free to create statutory goals flexible enough to tolerate state obstacles. Even so, Geier suggests this intent must be

54 Id. at 106.

55529 U.S. 861 (2000).

$56 \quad 15$ U.S.C. $\int_{1397}(\mathrm{k})$.

57 GEIER, 529 U.S. at 871 .

58 Id. at 872 .

59 Id. at 900 n. 16 (Stevens, J., dissenting). ("The [majority] contends, in essence, that a savings clause cannot foreclose implied conflict pre-emption.")

60 Id. at 888 (Stevens, J., dissenting). 
stated very clearly. We may be approaching the point where "clear statements" are necessary both to invoke and to avoid preemption. The answer to the second question is in the eye of the beholder. Although the presumption against preemption is in no danger of abandonment, it does - in our view occasionally get misplaced.

\section{CONCLUSION}

As American federalism makes clear, redundancy is complicated. The pushme-pull-you model of shared government offers big advantages, such as democratic responsiveness, innovation, and flexibility. But the costs are real, not the least of which is the judicial effort necessary to keep all players within their appropriate bounds. What makes this area of the law so fascinating is that, if you study it long enough, it will inevitably pit your principles against a desired outcome. States' rights look good to an environmentalist favoring stricter auto pollution laws in California or safer standards at New Jersey chemical plants. But states' rights arguments have also been used by courts to limit the protection of the nation's wetlands and immunize state agencies from environmental citizen suits. Conservatives have the same problem, sometimes struggling, for instance, to show why federal gun restrictions may not be foisted on the states but why federal marijuana restrictions may. ${ }^{61}$ Although not all of these cases involve preemption, they do involve the basic values at stake in the preemption debate, namely a concern for local democracy and state experimentation, on one side, and a desire for national uniformity and efficiency on the other.

61 See Gonzales v. Raich, 545 U.S. 1 (2005) (upholding despite Commerce Clause challenge federal criminal ban on the manufacture, distribution, or possession of marijuana by intrastate growers and users of marijuana for medicinal reasons). 